ELORE (ISSN 1456-3010), vol. 15 - 2/2008.

Julkaisija: Suomen Kansantietouden Tutkijain Seura ry.

[http://www.elore.fi/arkisto/2_08/hyk2_08.pdf]

\title{
Ajankohtaista: TYÖVÄEN KOKEMUSTA TAVOITTAMASSA
}

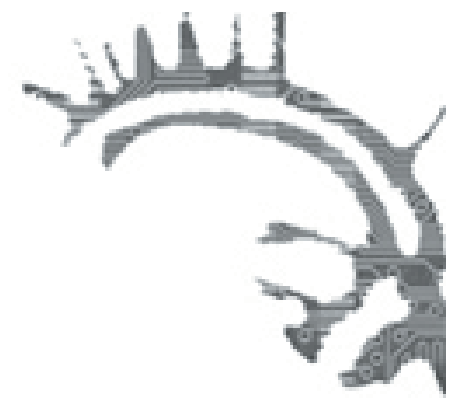

Työväen historian ja perinteen tutkimuksen seuran kesäseminaari Työväki ja kokemus 18.-19.8.2008, Nurmijärvi

\author{
Kirsi-Maria Hytönen ja Eerika Koskinen-Koivisto
}

Työväentutkijat kokoontuivat elokuussa Kiljavan opistolle Nurmijärvelle perinteiseen kesäseminaariinsa, jonka aiheena oli tällä kertaa monia tieteenaloja askarruttava teema, kokemus. Seuran puheenjohtaja, valtiotieteen tohtori ja tutkija Matti Hannikainen kertoi seminaarin aiheen kiinnostaneen monia, jopa siinä määrin, että saapuneista abstrakteista jouduttiin valitsemaan esitelmöitsijät monitahoisten kriteerien perusteella. Järjestäjät olivat pohtineet niin monitieteisyyttä, alueellista edustavuutta kuin aiheen keskittymistä olennaiseen. Seminaariin myös haluttiin eri vaiheissa olevia jatko-opiskelijoita. Työväentutkimuksen seuran etuna onkin erilaisten ihmisten ja tahojen yhteen saattaminen; seminaarissa oli tieteentekijöiden lisäksi myös museoväkeä, kirjastojen, arkistojen ja järjestöjen edustajia ja historianharrastajia. Pääpuheenvuoron ja esitelmien lisäksi ohjelmassa oli paneelikeskustelu aiheesta "Miten saadaan talteen suurten ikäluokkien muistot ja kokemukset ay- ja työväenliikkeestä?".

\section{RAJATON KOKEMUS JA MITEN SE SAAVUTETAAN?}

Seminaarin pääpuhujaksi oli kutsuttu dosentti, erikoistutkija Ulla-Maija Peltonen (Suomalaisen Kirjallisuuden Seura). Hänen puheenvuoronsa oli erityisen kiinnostava siksi, että pitkän tutkijanuransa aikana Peltonen on tutkinut kokemusta mutta on tietoisesti vältellyt määrittelemästä sitä. Hän pohti puheenvuorossaan seminaarin kannalta oleellista kysymystä: miten tutkijan on mahdollista saavuttaa kokemus?

Peltonen, joka on itse tutkinut muistelua vuoden 1918 tapahtumista ja sen jälkimaininkeja, totesi suomenkielisen sanan kokemus olevan yleisluonteinen ja kaksitahoinen sisältäen sekä ajatuksen harjaantuneisuudesta ja kokeneisuudesta (saksassa Erfahrung) että elämyksestä (Erlebnis). Molemmat kokemuksen aspektit, jotka myös 


\section{TYÖVÄEN KOKEMUSTA TAVOITTAMASSA}

liittyvät aikaan, ovat läsnä omaelämäkerrallisissa ja muisteluaineistoissa. Niistäkään aineistoista kokemus ei kuitenkaan ole selkeästi luettavissa, vaan eletty ja kerrottu ovat prosesseja, joissa kokemukset muotoutuvat aina uudelleen ja uudelleen.

Peltonen huomautti, että työväkeä 1960-luvulla määritellyt E. P. Thompson perusti klassikoksi kohonneen määritelmänsä työväen yhteiseen kokemukseen. Kokemus ei kuitenkaan ole määrittävänä käsitteenä ongelmaton: työväen kokemus rajaa sen omaksi ryhmäkseen ja sulkee pois ryhmän sisäiset erot. Ryhmien ja yksilöiden, meidän ja muiden kokemukset liittyvät myös tiedon tuottamiseen. Virallisen tiedon voidaan katsoa olevan ilmeistä ja yleistä, valmiiksi konstruoitua, jonka vastakohdaksi ja oheen epävirallinen toinen tieto tuo kokemuksellista ja yksityiskohtaista, tunnepitoista tietoa. Toinen tieto ei kuitenkaan ole helposti kommunikoitavissa ja se saattaa jopa olla täysin tabuoitua tai pelkästään viittauksenomaista, rivien välistä luettavaa. Miten tällaista kokemuksellista tietoa voi tavoittaa ja tulkita? Voiko tutkija vain luottaa siihen, mikä tuntuu sopivalta ja hyvältä, kuten etnologi Agnes Heller on muotoillut, vai pitääkö aineiston lukemisessa olla selkeä lukutapa? Peltonen kertoi kiinnittävänsä aineistoa lukiessaan huomiota epämääräisiin viittauksiin, erityisesti sellaisiin, joissa viitataan toisiin, piilossa oleviin toimijoihin ja asioihin, jotka vaikuttavat kerronnassa, mutta jotka eivät tule suoraan esiin. Hän esitteli esimerkkejä omasta aineistostaan ja sanoi seuraavansa antropologi Victor Turnerin tutkijoille suuntaamaa ohjetta olla mukana, katsoa kauempaa.

\section{KOKEMUS LÄHTEENÄ JA KOHTEENA}

Kahden seminaaripäivän aikana kuultiin kuusi esitelmää eri alojen jatko-opiskelijoilta. Kaikkiin esityksiin ehdittiin paneutua kunnolla, sillä seminaarin järjestäjät olivat päättäneet, että sekä puhujille itselleen että keskustelulle annetaan riittävästi aikaa. Harvan seminaarin jälkeen olemme olleet niin energisiä kuin tämän. Jatkoimme keskustelua seminaarin annista koko automatkan Jyväskylään.

Tutkiessaan kokemusta historioitsijat käyttävät usein lähteitä, jotka eivät ole alalle tyypillisiä ja tulkittavissa (pelkän?) lähdekriitikin avulla. Historioitsija Sami Suodenjoki (Tampereen yliopisto) tutkii ulkopuolisten kokemusta työväestön järjestäytymisestä 1900-luvun alun Urjalassa. Hän valotti tutkimuskysymystään yhden ihmisen, tämän kirjoittamien muistelmien ja tätä koskevien asiakirjamerkintöjen kautta. Suodenjoki tulkitsi tutkimansa henkilön olleen varsin erikoinen persoona, eräänlainen "kylähullu", jonka ympärillä sattui ja tapahtui. Ehkäpä juuri siksi tätä koskeva aineisto on säilynyt ja päätynyt tutkijan käsiin. Aineiston ennakkoluuloton käyttö avasi tutkijalle ja kuulijoille uusia näkökulmia työväenliikkeen ja pienyhteisön dynamiikkaan.

Historioitsija Jarkko Liedes (Helsingin yliopisto) tutkii työväenliikkeen alkuaikaa ja erityisesti käsityöväen järjestäytymistä työväenliikkeeksi. Liedes kertoi työväenliikkeen perustajien joukoissa olleen paljon suutareita ja että juuri käsityöläisammattien edustajat olivat vaikutusvaltaisia työväenliikkeen alkuvaiheissa. Näille huomiolle Liedes pyrkii löytämään syitä väitöskirjassaan. Historioitsija Lauri Keskinen 


\section{Kirsi-Maria Hytönen Ja Eerika Koskinen-Koivisto}

(Turun yliopisto) tarkastelee aluillaan olevassa väitöskirjassaan työläisurheiluseurojen roolia nuorten poliittisessa sosialisaatiossa. Keskinen pyrkii hyödyntämään kasvatustieteen ja sosiologian teorioita oppimisesta ja sosialisaatiosta, joten tutkimuksesta on tulossa monitieteinen.

Historioitsija Keijo Rantanen (Tampereen yliopisto) tutkii suuryritys Nokian varhaisempia vaiheita ja puunjalostuksen päättymistä Nokian tehtaalla. Rantasen käyttämä käsite deindustrialisaatio herätti keskustelua yleisön joukossa. Yhtäältä se koettiin ongelmalliseksi, liian suoraviivaiseksi ja ennalta määritteleväksi, toisaalta kaikkiin prosesseihin kuuluu erilaisia käänteitä ja katkoja, jotka eivät kuitenkaan välttämättä muuta kehityksen suuntaa. Muutoksen problematiikka askarrutti myös muita työväentutkijoita. Historian jatko-opiskelija, valtiotieteen tohtori ja metsänhoitaja Jaana Laine (Helsingin yliopisto) tutkii Suomen metsäteollisuudessa tapahtunutta suurta muutosta erityistesti metsätyömiesten näkökulmasta. Esitelmässään "Puolipuhtaasta tynkäkarsintaan, urakasta aikapalkkaan" hän puhui metsätyön palkkauksen muutoksesta 1950-2008. Laine käyttää aineistonaan paitsi metsätyömiesten haastatteluja myös alan työehtosopimuksia, joiden monimutkaisuus ja yksityiskohtaisuus kertoivat yleisölle, miten vaikeaa metsätyöläisten palkan määrittäminen on ollut.

Esitelmien herättämissä keskusteluissa nousi monta kertaa esiin sukupuolinäkökulman puuttuminen monesta - erityisesti historian tutkijoiden - esityksestä. Kaiken tutkimuksen keskiöön ei sukupuolinäkökulmaa tarvitse nostaa, mutta sen ohittaminen kokonaan sulkee tutkijan silmät tärkeiltä asioilta. Ei riitä, että sukupuolinäkökulman mukaan ottamiseksi sisällytetään tutkimukseen sekä naisia että miehiä, vaan huomiota tulisi kiinnittää myös sukupuolen problematisointiin ja sukupuolittuneisiin.

\section{TuOREITA JUlKaISUJA, UUSIA NÄKÖKULMIA}

Seminaarin viimeinen esitelmöitsijä, perinteentutkija Kaisu Kortelainen (Joensuun yliopisto) esitteli syksyllä 2008 julkaistavaa väitöskirjaansa Penttilän sahayhteisöstä. Hän kertoi tutkimuskysymyksistään, käyttämistään aineistoista (muistitietohaastattelut, valokuvat ja kartat) ja näkökulmista sekä eritteli monivaiheista tutkimusprosessiaan. Erityisesti Kortelaisen näyttämät valokuvasarjat ja tehdasyhteisöstä piirretyt kartat (ks. myös Kortelainen 2006) saivat myös yleisön eläytymään tutkimusaiheeseen. Kortelainen väittelee marraskuussa. Hänen tutkimuksensa julkaisee Suomalaisen Kirjallisuuden Seura.

Kiljavanrannan kesäseminaarissa julkaistiin myös Työväen historian ja perinteen tutkimuksen seuran uusi Väki voimakas -sarjan 21. kirja Työväki läbtee - mibin sunntaa tutkimus?, joka perustuu edellisen seminaarin tuottoon. Teoksessa tarkastellaan työväentutkimuksen nykytilaa ja tulevaisuuden haasteita. Sen näkökulmat ovat tuoreita, monipuolisia ja kriittisiä - kuten myös tämän kesäisen seminaarin esitelmät ja monipolviset keskustelut. 


\section{TYÖVÄEN KOKEMUSTA TAVOITTAMASSA}

\section{KiRJALlisUUS:}

HANNIKAINEN, MATTI \& LOHIKOSKI, PIA (toim.) 2008: Työväki läbtee - mihin suuntaa tutkimus? Helsinki: Työväen historian ja perinteen tutkimuksen seura.

KORTELAINEN, KAISU 2006: Tehdasyhteisöstä kirjoitettu kartta. - Seppo Knuuttila \& Pekka Laaksonen \& Ulla Piela (toim.), Paikkea. Eletty, kuviteltu, kerrottu. Kalevalaseuran vuosikirja 85. Helsinki: SKS.

- 2008: Penttilän sahaybteisö ja työläisyys. Muistitietotutkimus. Helsinki: SKS.

Filosofian maisterit Kirsi-Maria Hytönen ja Eerika Koskinen-Koivisto valmistelevat väitöskirjojaan Jyväskylän yliopiston historian ja etnologian laitoksessa. He puhuivat työväentutkijoiden kesäseminaarissa väitöskirjojansa yhdistävästä teemasta, naisten kokemuksista tehdastyöstä toisen maailmansodan aikana. 